\title{
Electoral Institutions and Electoral Violence in Sub-Saharan Africa
}

\author{
HANNE FJELDE AND KRISTINE HÖGLUND*
}

Political violence remains a pervasive feature of electoral dynamics in many countries in Sub-Saharan Africa, even where multiparty elections have become the dominant mode of regulating access to political power. With cross-national data on electoral violence in Sub-Saharan African elections between 1990 and 2010, this article develops and tests a theory that links the use of violent electoral tactics to the high stakes put in place by majoritarian electoral institutions. It is found that electoral violence is more likely in countries that employ majoritarian voting rules and elect fewer legislators from each district. Majoritarian institutions are, as predicted by theory, particularly likely to provoke violence where large ethno-political groups are excluded from power and significant economic inequalities exist.

Over the past two decades, nearly all Sub-Saharan African states have adopted some form of electoral democracy in which the highest political offices are filled through regular, multiparty elections. In theory, elections constitute a key pillar of democratic governance by facilitating representation, ensuring accountability and peacefully regulating access to political power. ${ }^{1}$ Indeed, a growing number of African leaders leave office after electoral defeat or when meeting their term limits, indicating the rising importance of formal institutions for regulating access to political power. $^{2}$ At the same time, however, political violence still remains a pervasive trait of electoral periods in many of Africa's multiparty systems. Thus, although countries such as Mozambique, Namibia and Zambia have recently experienced largely peaceful elections, widespread electoral violence by both government and opposition actors has marred recent elections in Kenya, Nigeria and Zimbabwe. This violence threatens to undermine not only electoral integrity, but also democratic gains in these countries. What factors can explain these differences in electoral violence?

We have used cross-national data on electoral violence in Sub-Saharan African elections between 1990 and 2010 to develop and test a theory that links the use of violent electoral tactics to the high electoral stakes that are put in place by majoritarian electoral institutions, such as plurality rules and small electoral districts. Majoritarian systems tend to reward larger parties disproportionately and impose high barriers on political representation. Where democratic institutions are consolidated, the threat of a decisive electoral defeat is not sufficient to motivate the use of violence. However, across Africa these formal rules tend to interact with powerful

* Department of Peace and Conflict Research, Uppsala University (email: hanne.fjelde@pcr.uu.se). The authors wish to thank Stephan Hamberg, Lisa Hultman and participants at the Institutions for Sustainable Peace workshop in San Diego, 2012, for helpful comments on previous versions. The research was funded by grants from the Research Council of Sweden, project 421/2010/1515 and the Research Council of Norway, project 217995/V10. Data replication sets and online appendices are available at http://dx.doi.org/10.1017/S0007123414000179.

1 Cf. Dahl 1971; Huntington 1991.

2 Posner and Young 2007. 
informal institutions, such as patron-client relationships, that tie political power to economic benefits for the individual politician, his family and his ethnic kin.

These informal institutions heighten the stakes of the electoral contest in two critical ways. First, politicians are motivated to seek public offices for the privileges they entail, and voters are motivated to support politicians from their own ethnic group who will be in a position to allocate more state resources to that ethnic group. Secondly, an electoral advantage is provided to those politicians who already have political power. In this context, the winner-takes-all dynamic introduced by majoritarian systems reinforces the perception of electoral competition as a zero-sum contest for the dominance of the state and its sources of patronage. The perceived costs of electoral defeat and the fear of permanent exclusion under majoritarian rules create incentives on both sides of the incumbency divide to employ violence to influence the outcome of the elections.

Based on the argument presented above, we hypothesize that electoral violence will be more likely in African countries employing majoritarian electoral rules. From it, we also derive two additional expectations. First, we expect that elections within majoritarian institutions will be particularly prone to violence when large ethno-political groups are excluded from political power. This is because an opposition with a sizeable electoral constituency might represent a more credible threat to the incumbent party and thus motivate both sides to rely on violent strategies to win an election. Secondly, we expect that majoritarian institutions will be particularly detrimental in countries with high levels of economic inequality because the stakes of the elections and the costs of electoral defeat increase when both political power and economic wealth are narrowly distributed and tightly intertwined.

Our results confirm these expectations and show that electoral violence is more likely in countries with majoritarian rules and small electoral districts than it is in proportional representation (PR) systems. We also find that majoritarian institutions are more likely to lead to electoral violence in situations where large ethno-political groups are excluded from formal political power and in situations where land is controlled by a narrow segment of society.

Our study complements an extensive literature concerning the influence of electoral institutions on conflict prevention and management in divided societies. ${ }^{3} \mathrm{We}$ are making two contributions to this literature. First, starting from existing arguments about the winner-takes-all dynamics of majoritarian rules, our study places a particular emphasis on how informal institutions contribute to shaping the incentive structure that guides political behaviour within these formal institutions. It thus provides a mechanism for linking electoral systems to the risk of political violence in Sub-Saharan Africa. Secondly, our analysis extends the empirical domain of this literature by moving beyond the focus on civil war to concentrate explicitly on electoral violence. These phenomena do not generally overlap. Whereas the launch of a civil war often tends to represent an exit strategy from the domain of regular political competition, violent electoral tactics are often employed alongside other constitutional and non-constitutional strategies for retaining power. Electoral violence thus raises particular challenges for democratic consolidation and increases the risk of a return to authoritarian rule in Africa's democratizing states. It requires a distinct framework of analysis. Yet, cross-case comparative studies on this topic still remain relatively scarce.

In the next section, we conceptualize electoral violence as a strategic effort to influence electoral outcomes. We then briefly situate our study in relation to existing research. We proceed to outline our theoretical argument and empirical implications before presenting the dataset, research design and our empirical findings.

${ }^{3}$ Cf. Horowitz 2003; Lijphart 1977; Lijphart 2004; Reilly and Reynolds 2000; Reynolds 1999; Sisk 1996. 


\section{ELECTORAL VIOLENCE AS MANIPULATION}

The comparative study of elections in democratizing and non-democratic regimes has boomed over the last decade. ${ }^{4}$ Consequently, a growing body of research is devoted to the study of strategies of electoral manipulation in which political elites seek to influence the outcome of elections by circumventing democratic procedures. ${ }^{5}$ One such strategy is the use of violent electoral tactics, i.e., the use of physical violence or coercive intimidation to reduce the uncertainty of the electoral outcome or to influence the political trajectory following the announcement of electoral results. ${ }^{6}$

This study complements existing research on electoral violence that highlights the incentive structures that lead political elites to use violence strategically during election periods. ${ }^{7}$ HafnerBurton, Hyde and Jablonski, for example, present cross-national evidence showing that incumbent governments rely on violence, such as harassment of opposition candidates or voter intimidation, to prevent an unfavourable electoral outcome when they fear being defeated at the ballot box. ${ }^{8}$ Klopp and Zuern have drawn on evidence from Kenya and South Africa to show how incumbents use, for example, the security apparatus, informal militias and orchestrated mass rallies to engage in violent electoral tactics to derail a threatening opposition by, for instance, depressing voter turnout in particular areas. ${ }^{9}$ They also discuss how violence can be used during all parts of the electoral cycle to mobilize electoral constituencies, such as may be done by the opposition side during a period of coalition building after an election. Many existing studies have linked even seemingly local, spontaneous and mass-based manifestations of violence during elections to the elites' incentives to draw in, politicize and mobilize larger constituencies. ${ }^{10}$ Thus, Wilkinson shows how some Indian politicians strategically instigate inter-ethnic riots to ensure the electoral support of their own ethnic group when the electoral race is particularly close. ${ }^{11}$ It must be noted that not all election-related violence is elite-orchestrated and pre-planned, but often emerges as swift, bottom-up mobilization in protest against electoral events. However political elites often play a central role in defining the limits and the meanings of even spontaneous and localized riots or resource conflicts during election periods. ${ }^{12}$

Our study is related to three existing research agendas. First, it builds on the relatively limited, but growing, body of systematic studies dealing specifically with electoral violence. Rather than focusing on the influence of particular institutions, existing studies have emphasized the role of institutional weakness, for example, in periods of democratic transition or following armed conflict. ${ }^{13}$ One exception is the work of Hafner-Burton, Hyde and Jablonski, who find that the absence of institutional constraints on governments increases their reliance on violent electoral strategies. ${ }^{14}$

${ }^{4}$ Cf. Gandhi and Lust-Oskar 2009; Schedler 2006.

5 Cf. Birch 2007; Lehoucq 2003; Schedler 2002.

6 Straus and Taylor 2012, 19.

7 Cf. Arriola and Johnson (2012) on power-sharing in post-conflict societies; Daxecker (2012) on electoral monitoring; and Hafner-Burton, Hyde and Jablonski (2013) on the effect of electoral violence on leadership tenure.

${ }^{8}$ Hafner-Burton, Hyde and Jablonski 2014; see also Collier and Vicente 2012.

${ }^{9}$ Klopp and Zuern 2007.

10 cf. Boone 2011; Mueller 2008; van Klinken 2002; Klopp and Zuern 2007.

11 Wilkinson 2004.

12 See, for example, Horowitz $(2001,231 \mathrm{ff}$.) for a discussion of the role of elite organization. In line with a strategic interpretation, several studies place electoral violence within the same category of illicit strategies of electoral manipulation as vote-buying and electoral fraud (cf. Bratton 2008; Collier and Vicente 2012; Schedler 2002).

13 Arriola and Johnson 2012; Höglund 2009; Linebarger and Salehyan 2012.

14 Hafner-Burton, Hyde and Jablonski 2014; see also Arriola and Johnson (2012) on power-sharing settlements and institutions in post-conflict societies. 
Our study also ties in with the literature debating the significance of electoral institutions in mediating the risk of armed conflict more broadly. Several scholars have advocated proportional electoral rules as part of a broader package of power-sharing institutions that can reduce the risk of armed conflict in divided societies. ${ }^{15}$ However, the debate about the merits of majoritarian versus proportional electoral institutions is inconclusive, particularly when looking beyond a few well-researched case studies to broader, cross-national empirical evidence. ${ }^{16}$ Furthermore, it is difficult to draw conclusions directly from this literature concerning the risk of electoral violence. Contrary, for example, to ethnic rebellions, violent electoral strategies generally do not represent an exit strategy from the realm of political competition. Rather, they are pursued alongside other constitutional or non-constitutional strategies with which politicians seek to attain or retain power in a political contest. ${ }^{17}$ Hence, even if particular electoral institutions might contribute to preventing the violent breakdown of institutional order, previous research has not addressed how electoral institutions might or might not motivate actors to pursue violent strategies to influence political outcomes within these institutions. Although our study also relates to research showing how elections can polarize politics and act as a catalyst for armed conflict, ${ }^{18}$ electoral violence and armed conflict are generally not overlapping phenomena. ${ }^{19}$ Electoral violence thus requires a separate framework of analysis.

\section{THEORETICAL ARGUMENT}

The electoral system is one of the most significant political institutions in terms of defining the strategic context of electoral competition. In the words of Mozaffar, electoral systems 'structure political conflict over distributional outcomes in democratic polities' ${ }^{20}$ The choice of electoral laws, i.e., the method for translating votes into seats, has profound effects on patterns of political mobilization and representation. ${ }^{21}$ Majoritarian systems (most commonly exercised as single-member plurality or absolute majority) typically magnify the electoral success of large parties, whereas PR electoral formulas and larger electoral districts tend to lower barriers to representation for smaller parties. ${ }^{22}$ Electoral institutions thus have important distributive

15 cf. Lijphart 1977; Lijphart 2004; Reynolds 1999. For an overview of these arguments, see e.g. Horowitz 2003; Reilly and Reynolds 2000; Sisk 1996. Proponents of PR systems emphasize the importance of minority representation, the accommodation of plurality, and power-sharing mechanisms for conflict prevention (Lijphart 1977; Lijphart 2004; Reynolds 1999). Their critics suggest, however, that the institutional entrenchment of group cleavages politicizes ethnicity and invites ethnic outbidding that works to undermine inter-group accommodation and increases the risk of violence (cf. Horowitz 1985; Horowitz 2003; Lardeyret 1991. However, see Huber 2012 for a challenge to this argument). Majoritarian systems are assumed to induce vote pooling and electoral coalitions spanning more than one group (Horowitz 1985; Horowitz 2003) and to facilitate accountability and government effectiveness, which might promote long-term stability (Barkan 1995; see also Knutsen 2011 for a review).

${ }^{16}$ Lijphart $(2004,107)$ describes a 'strong scholarly consensus' in favour of consociationalist institutions. Cross-national studies on the risk of ethnic rebellion (Cohen 1997; Saideman et al. 2002) and civil war (Reynal Querol 2002; Schneider and Wiesehomeier 2008) report cross-national evidence to support such contentions. However, in a comprehensive empirical study Selway and Templeman (2012) did not find any conflict-reducing effect of PR systems in diverse societies.

17 On the relationship between violence and electoral competition as strategic substitutes or complements, see Dunning (2011).

18 Brancati and Snyder 2013; Cederman, Gleditsch and Hug 2012; Flores and Noourdin 2012; Snyder 2000.

19 Bekoe 2012; Höglund 2009.

20 Mozaffar 1998, 81.

21 Birch 2005; Lindberg 2005.

22 The distinction between majoritarian and PR systems is a simplified dichotomy. Each category contains a number of different options regarding electoral formulas, thresholds, and district sizes, and various countries combine different systems. 
consequences for the parties involved. ${ }^{23}$ By disproportionately rewarding the dominant party and introducing higher barriers for representation, pure majoritarian rules might lead minority parties to feel that they are underrepresented or even excluded from political power. ${ }^{24}$ Because they are designed to produce clear winners and decisive outcomes, majoritarian electoral systems tend to heighten the stakes of electoral contests.

In places where democratic institutions are well established, prospects of electoral defeat should not be sufficient to motivate politicians to engage in violent electoral tactics. Formal institutions are crucial in 'institutionalizing uncertainty', to use Przeworski's terminology, and they transfer power from individual political actors by means of a set of rules. ${ }^{25}$ The strength of these institutions motivates actors to comply with democratic rules and to accept electoral defeat because they convey a certainty that the losers will still be allowed to advance their interests in the future. However, in Africa's electoral regimes the workings of these formal institutions are influenced by powerful informal institutions that also shape the electoral contest. By informal institutions, we refer specifically to patterns of patron-client relationships that are understood here as the joint practices of clientelism (the expression of political loyalty to providers of patronage) and political corruption (the misuse of public office for private gain). ${ }^{26}$ These informal institutions influence the value that political actors attach to complying with formal electoral rules, regardless of the election outcome, as opposed to making their commitment to democratic, non-violent procedures contingent on the election resulting in the actors' favour.

In many of Africa's emerging democracies, pervasive patron-client relations increase the cost of electoral defeat. ${ }^{27}$ These relationships mean that access to state power often translates into control over large public funds and opportunities for illicit rent-seeking for individual politicians, and this increases personal stakes in elections. Importantly, however, patron-client relations also have implications for politicians' interaction with their electoral constituencies, and political mobilization in Africa's multiparty regimes has often come to revolve around promises of benefits by politicians in return for voters' support. ${ }^{28}$ Viable electoral coalitions often based on narrow geographical or ethnic constituencies - are built through patronage spending on private goods, jobs, land, or even through cash transfers, as well as the provision of access to communal goods such as development resources.

Adding to the salience of electoral outcomes is the fact that contending patron-client networks are often structured along ethnic lines. Within the context of spoils-based politics, political parties mobilize voters less on the basis of programmatic platforms and more on the basis of regional affiliation and ethnic loyalties. ${ }^{29}$ According to Posner, for example, voters' expectations regarding whether they will be included in the patronage coalition are strongly related to whether the politician who controls the resource is from their ethnic group. ${ }^{30}$ In the absence of a strong commitment to providing public goods, the bid for economic benefits and the political contest become intertwined and the prosperity of the ethnic community or the

${ }^{23}$ Benoit 2004, 366.

${ }^{24}$ Lindberg 2005; Reynolds 1999; Sisk 1996.

25 Przeworski 1991.

${ }^{26}$ In contrast to formal institutions codified in law, informal institutions are rules of political behaviour 'created, communicated and enforced outside of officially sanctioned channels' (Helmke and Levitsky 2004, 727). A range of informal institutions exists (cf. Helmke and Levitsky 2004 for a review), but many scholars recognize the particular importance of patron-client relationships as a powerful informal institution in Africa's electoral regimes (cf. Bratton 2007; Diamond 2008; Hyden 2006; van de Walle 2003).

${ }^{27}$ Bratton 2007; Lindberg 2003.

${ }^{28}$ Lindberg 2003; Posner 2007; van de Walle 2003; Wantchekon 2003.

${ }^{29}$ Lynch and Crawford 2012; van de Walle 2003; Wantchekon 2003.

${ }^{30}$ Posner 2007; see also van de Walle 2003. 
region is perceived to depend on having one of their own in power. ${ }^{31}$ African opposition parties have often mobilized from different ethnic support bases than the ruling party precisely on the basis of exclusionary patronage systems. ${ }^{32}$ This system of resource allocation further raises the stakes of electoral competitions.

In summary, patron-client relations might contribute to a perception of the electoral contest as a zero-sum contest between a country's ethno-regional communities. In such a contest, electoral defeat implies not only political marginalization, but is also perceived to have devastating economic consequences for those involved both at the elite and constituency level. ${ }^{33}$ The effect of the electoral system on politicians' incentives to engage in violent electoral tactics and on their constituencies' willingness to be mobilized for such violence must be understood within this context. Thus, the type of formal electoral rules has a particular significance in that these rules intensify or mitigate the incentive structures that are produced by the informal institutions described above. ${ }^{34}$

Majoritarian electoral institutions further reinforce the stakes of the electoral contest. The winner-takes-all dynamic and the high political premium awarded to the largest party under majoritarian rules imply that the electoral stakes are higher than they are under PR systems, where electoral outcomes tend to disperse the nodes of political power across a broader range of groups. In majoritarian systems, even political parties with significant followings might risk being without representation in parliament. When the individual politicians' and the electoral constituency's access to economic resources are seen to be closely linked to having a stake in state power, the high cost of electoral defeat might precipitate the use of violent electoral strategies.

The actual effect of electoral institutions on group representation is often dependent on the geography of electoral constituencies. When ethnic groups are concentrated in particular regions and constitute local majorities, the level of disproportionality in representation entailed by singlemember plurality systems is reduced. ${ }^{35}$ Majoritarian systems might, in these situations, have other benefits such as increased accountability based on the link between individual politicians and their geographic constituencies. ${ }^{36}$ However, even if ethnic groups live in geographically concentrated areas, African electoral constituencies tend to be ethnically heterogeneous. When dominated by one ethno-political group, the use of single-member districts tends to translate this dominance into ethnic fiefdoms at the local level. ${ }^{37}$ Single-member districts provide the dominant national party with the institutional means to co-opt the regional or ethnic constituency, and majoritarian formulas give the dominant party a significant advantage vis-à-vis the opposition. ${ }^{38}$ As a result, electoral competition often taps into and reinforces localized competition between groups.

In this context, one of the advantages of majoritarian systems - their ability to produce a strong opposition party able to mount a credible threat to the incumbency - might, in fact, heighten the risk of violence. Over time, the ability of majoritarian systems to facilitate strong parliamentary oppositions could provide a check on the government and thus facilitate democratic consolidation. However, the short-term effect might be to increase the government's fear of electoral defeat and potentially to sharpen the incentives for both government and

31 Bates 1983; Scarritt and McMillan 1995; Wimmer 1997.

32 Kirschke 2000.

33 Kirschke 2000, 390.

34 Helmke and Levitsky 2004; Mueller 2008.

35 Barkan 1995; Wagner and Dreef 2014.

36 Barkan 1995. List PR systems, for example, have been criticized for making members of parliament upwards accountable to powerful party bosses rather than to their electoral constituencies (Southall 2009, 453).

37 Cho 2010; Reilly and Reynolds (2000, 469); Reynolds 1999.

38 Mozaffar 1998. 
opposition to resort to violent manipulation. ${ }^{39}$ As noted by Birch, the translation of votes into seats in single-member majoritarian systems often leads to situations in which a very small margin of votes separates winners from losers. This means that a small number of votes could swing the outcome of the election in that district in favour of a particular candidate. ${ }^{40}$ She links this to the higher prevalence of electoral malpractice under majoritarian systems. Higher stakes and close competition are similarly likely to increase the incentives to engage in violent electoral manipulation.

Majoritarian institutions that disproportionately reward larger parties could also reinforce the incumbency advantage already conferred by patron-client relationships. With the introduction of multiparty elections in Africa, the locus of clientelism has shifted from the state apparatus to political parties. Often, a poorly resourced opposition finds itself competing with a government party that benefits from unmitigated control of state assets and, therefore, can increase its electoral advantage through the distribution of state patronage. ${ }^{41}$ In majoritarian systems, the high political premium awarded to the party with the largest vote share might serve to buttress the dominant position of the government party. This might further polarize the electoral contest both by making government parties feel less constrained in opting for illegitimate strategies of electoral manipulation and by breeding frustration among opposition parties. The organizational weakness of political parties in Africa's emerging democracies implies that without representation the losing parties might not survive electoral defeat to contest the next election. The volatility of opposition parties since the introduction of multiparty politics in the region is suggestive of this. ${ }^{42}$ The interaction of formal and informal institutions thus means that the electoral contest tends towards a zero-sum dynamics. The fear of permanent exclusion from political power might increase the risk of electoral violence by undermining the losing side's commitment to the formal, democratic rules of the game.

PR electoral institutions, in contrast, tend to increase the likelihood that even minority candidates will commit to democratic rules because such institutions are more likely to guarantee them sufficient representation to 'stay in the game' until the next election and to secure them a stake in the allocation of state resources. The introduction of a PR system in itself might not be able to alter the dominance of the government party in the African context, but even the prospect of a 'consolation prize' in the form of some representation, might motivate opposition candidates to commit to the democratic process and reduce the incentives for electoral violence. ${ }^{43}$ More generally, proponents of PR systems as a tool for conflict management in divided societies hold that the inclusiveness of such systems is more likely to facilitate inter-elite co-operation and make power sharing between groups more visible. ${ }^{44}$ Democratic backlash is less likely where both majority and minority parties can claim to have a stake in the political institutions. ${ }^{45}$

Our argument suggests that the incentive structures for politicians to engage in violent electoral tactics must be understood as a joint product of majoritarian institutions that are geared

39 Birch (2005), however, questions the ability of majoritarian systems to produce a balanced party system in Africa. She shows that in the 'third wave democracies' where parties are weakly institutionalized and poorly resourced, single-member majoritarian rules have often ensured continued dominance of a single party alongside a fragmented, regionalized and volatile opposition.

40 Birch 2007.

41 Makinda 1996, 567; Rakner and van de Walle 2009.

42 cf. Bogaards 2000; Rakner and van de Walle 2009.

43 Studies of African party systems show that the largest party is still dominant in PR systems even though such systems are usually associated with less dominant parties, a larger number of legislative parties, lower disproportionality in votes-to-seat translation, and lower levels of electoral volatility (cf. Mozaffar and Scarritt 2005; Rakner and van de Walle 2009, 108).

44 Lijphart 1977; Lijphart 2004; Reynolds 1999; Sisk 1996.

45 Linz and Stepan 1996. 
towards producing all-out winners and losers and the informal institutions of patron-client relations that heighten the costs of electoral defeat. This does not necessarily mean, however, that the level of political corruption or of politicians' use of exclusionary clientelist policies - as opposed to campaigning on public-good platforms - will vary systematically across different electoral institutions. Rather, we assume that in both PR and majoritarian systems political positions will to some extent be valued for the resources they provide for the individual politician and his/her family and close kin, and that voters will seek to gain access to state resources by giving their electoral support to members of their own ethnic group. ${ }^{46}$ The difference lies in the way we believe that majoritarian electoral institutions reinforce, rather than mitigate, these high electoral stakes.

Observers of African politics have noted that the actual amount of resources that trickles down the patronage networks to the level of the individual voter is often very small. ${ }^{47}$ If this is so, then the inclusionary dynamics of PR systems might primarily work by facilitating elite accommodation across a broader segment of the society's groups. However, regardless of how much of the 'national cake' is in fact allocated based on changing electoral coalitions, the perception among electoral constituencies that the opportunity for their community to 'eat' hinges on having one of their own in power might itself facilitate mobilization for violent electoral strategies when their candidate is threatened with an all-out electoral defeat.

There is a debate about the actual distributive consequences of the different electoral systems. ${ }^{48}$ Some studies suggest that individual political accountability, close electoral competition, and majority government associated with majority rules provide a check on rentseeking behaviour and a large government sector. ${ }^{49}$ Others argue, however, that majoritarian systems can reinforce the tendency for the link between politicians and their constituencies to centre on clientelist accommodation within narrow networks of distinct ethno-regional constituencies. ${ }^{50}$ Commenting on the single-member plurality system in Kenya, Southall remarks that "it consolidated the political culture of "big men" [...] electoral appeal became heavily dependent on the dispersal, or promise of dispersal, of patronage, both in terms of electoral campaign expenditure and the securing of benefits from the centre for the constituency or particular constituents'. ${ }^{51}$ Quantitative evidence suggests that larger electoral districts, more continuous mapping of votes to seats, and the enhanced representation of group interests in PR systems all reduce the share of public spending going to narrowly targeted constituency goods and increase public spending on universal, distributive programmes targeting geographically dispersed groups of voters. ${ }^{52}$ These findings would suggest that the electoral contests under majoritarian systems have a higher likelihood of turning into a perceived zero-sum contest between distinct electoral constituencies, thereby entailing a higher risk of electoral violence. Based on the above discussion, we derive the following hypothesis:

HYPOTHESIS 1: The risk of electoral violence is higher in countries with a majoritarian electoral system than in those with a PR system.

46 Posner 2007; Wantchekon 2003.

47 van de Walle 2003.

48 cf. Knutsen 2011.

49 Persson and Tabbelini 2003; Persson, Tabellini and Trebbi 2003. However, small district sizes tend to be associated with higher levels of corruption making the net effect of majoritarian institutions ambiguous (Persson and Tabbelini 2003).

50 cf. Sisk and Reynolds 1998, 24.

51 Southall 2009, 449.

52 Knutsen 2011; Persson and Tabellini 2004; see also Cho 2010; Weaver 2002, 114. 
The argument presented above emphasizes the embeddedness of electoral institutions in societal characteristics. Specifically, our discussion about patron-client networks as a powerful informal institution in African politics highlights ethno-political exclusion and a narrow concentration of economic resources as factors that add to the importance of electoral rules by influencing the stakes of the electoral contest. ${ }^{53}$ Although our argument links these traits specifically to the workings of patron-client networks, the degree of exclusion and wealth concentration vary substantially across African countries and party systems. We thus examine the effect of the interaction between electoral rules and these societal characteristics more directly.

Our argument suggests that the risk of electoral violence is associated with the prospect of large electoral constituencies failing to achieve representation under a winner-takes-all majoritarian electoral system. Electoral constituencies might have different sources of group affiliation, and it is the risk of permanent exclusion, rather than the group composition, that creates incentives for violent electoral tactics. However, political coalitions in Africa tend to be structured along ethnic lines and ethnicity has been a particularly salient resource for the mobilization of political action across the continent. ${ }^{54}$ Where political exclusion follows ethnic lines, exclusion is particularly likely to reinforce the development of grievances and encourage political mobilization. ${ }^{55}$

We argue that majoritarian electoral institutions are particularly likely to lead to the use of violent electoral tactics in situations where large ethno-political groups are excluded from state power. The size of the excluded group is important because it shapes the perception among both the electoral constituency and the politicians who represent them of whether they could be part of a winning coalition with access to state resources. ${ }^{56}$ Politicians who draw their electoral support from larger excluded groups are also more likely to be in marginal positions when the outcome of the elections could go either way. These opposition politicians are, therefore, also more likely to constitute an electoral threat to those in government and thus increase the incentives to use violent tactics such as detentions, harassment or voter intimidation. Based on this, we derive our second hypothesis:

HYPOTHESIS 2: The risk of electoral violence under majoritarian electoral systems will increase with the size of the largest excluded ethno-political group.

Our argument identifies a predicament in the way that political power is used to lay claim to economic resources - often within a context where economic opportunities in the private market are relatively scarce compared to those that arise through control over government agencies, public funds or state property. ${ }^{57}$ Recent elections in Zimbabwe illustrate how the close relationship between political power and economic resources can contribute to a violent electoral contest. Through forcible acquisition, violent evictions and resettlement schemes, land has repeatedly been used as a patronage resource to mobilize electoral support in favour of the governing party, ZANU $\mathrm{PF}$, with much of it going to party elites. ${ }^{58}$ In the run up to the 2008 election, ZANU PF instilled fear among the newly landed elite that victory by the opposition would lead to their eviction, and this led many of them to participate in violence during the election. ${ }^{59}$ Our argument suggests that these economic incentives can raise the stake of the electoral competition above the threshold at

53 Mozaffar, Scarritt and Galaich 2003; Reilly and Reynolds 2000, 426.

${ }^{54}$ Bates 1983, Fearon 2006; Posner 2004; Scarritt and McMillan 1995.

${ }_{55}$ Cederman, Wimmer and Min 2010; Stewart 2008.

56 Birnir 2007, 163; Posner 2007.

${ }^{57}$ Boone 2009.

${ }^{58}$ Boone and Kriger 2012.

59 Electoral contests in Cote d'Ivoire and Kenya display very similar dynamics (Boone and Kriger 2012). 
which political candidates and voters can 'afford to lose' the election. ${ }^{60}$ Whereas PR systems could diffuse these high stakes by dispersing the nodes of political power, the winner-takes-all dynamic under majoritarian institutions reinforces them.

An implication of this argument is that the combination of majoritarian institutions and a narrow concentration of wealth will lead to high-stakes elections with a high risk of election violence. We take the concentration of land - arguably the most important source of wealth in Africa's agrarian economies - to be a proxy for the costs of electoral defeat for those in power. Boix, for example, argues that elite resistance to democratization will increase with the inequality of land holdings and that a narrow concentration of wealth increases the economic losses of the elites if the tax rate were to shift to reflect the preference of the median voter. ${ }^{61} \mathrm{We}$ also assume a substantial overlap between political and economic class and that a narrow concentration of wealth significantly heightens the cost of political defeat under majoritarian systems that favour decisive victories and disproportionately reward the winning side. With a more even distribution of wealth across society, the competition for political power is likely to be less geared towards zero-sum results even in majoritarian systems. This leads to our third hypothesis:

HYPOTHESIS 3: The effect of majoritarian electoral systems on electoral violence will increase with higher levels of land inequality.

\section{DATA AND RESEARCH DESIGN}

Our argument suggests that the institutional framework of the elections influences the risk that a country will experience physical violence and coercive intimidation in relation to electoral processes. We evaluate these expectations based on a dataset of monthly observations including all countries holding executive or legislative elections in Sub-Saharan Africa within the period of 1990-2010. Africa is one of the regions that experienced the most radical changes in its political outlook as a part of the third wave of democratization. Most African countries introduced multiparty elections in the 1990s, and these represent examples of unconsolidated regimes with a recent history of authoritarian politics. Because our argument centres on political competition in a context where democratic institutions remain weakly consolidated, SubSaharan Africa is a suitable sample. These countries also display considerable variation both in their institutional electoral frameworks and their experiences with electoral violence.

To identify electoral regimes, we use the National Elections across Democracy and Autocracy (NELDA) dataset, which provides detailed information on all election events in the time period studied. ${ }^{62}$ We include countries where elections were held for a national executive figure or for a national legislative body and in which voters directly elected the representatives to the national post in question. Based on these criteria, the dataset includes forty-seven countries and 8,466 monthly observations. ${ }^{63}$

Data on electoral violence for the 1990-2010 period is from the Social Conflict in Africa Database (SCAD, version 3.0). ${ }^{64}$ This is an event dataset that codes instances of social disturbances in Africa - such as demonstrations, strikes, riots, and government harassment - based

60 Boone 2009.

61 Boix 2003; see also Przeworski 1991.

62 Hyde and Marinov 2012.

63 For countries holding their first election within the time span of the dataset, the country is included in the analysis six months prior to the election month.

64 Salehyan et al. 2012. 
on Lexis Nexis searches of news wires. All events are coded by issue, and in the construction of our dependent variable we focus on those violent events that are coded as explicitly related to elections. ${ }^{65}$ Some studies of electoral violence have chosen an alternative approach by defining all political violence that occurs within a particular time frame around elections to be electoral violence. ${ }^{66}$ We identify electoral violence by issue - not simply by timing - for two reasons. First, electoral violence can occur at any time during an electoral cycle. Forcible displacement of voters ahead of voter registration and candidate intimidation during party primaries are two examples of electoral violence occurring well before the electoral campaigning and voting operations begin. Secondly, an approach that simply includes all violent events during a delineated period around elections independent of issues risks pooling together very heterogeneous forms of political violence, of which only some are related to the elections. Some of this violence might include armed conflict events, and this might weaken the explanatory power of theories relating specifically to electoral violence.

Besides the coding of election-related issues, another advantage of the SCAD data relative to other data sources is the inclusion of non-lethal events. Electoral violence includes coercive intimidation or physical violence that is not necessarily fatal. Because the SCAD data differentiate between the government and the opposition as perpetrators of violence, we are also able to examine the potentially important differences in patterns of electoral misconduct by these respective actors. ${ }^{67}$ We constructed two main dependent variables. Government Violence included all election-related violent activities waged by government authorities or by actors affiliated with the government. Opposition Violence included all election-related violent activities by non-government actors that are 'anti-government' or directed towards a distinct 'other' group or government authorities according to the SCAD codebook. ${ }^{68}$ Both variables are coded as dichotomous and have a value of 1 if any election-related violent event occurred that month or 0 if none occurred.

Our main independent variables of interest are related to the institutional framework of the elections. We distinguish majoritarian systems from other forms of electoral systems based on two measures of electoral law. First, based on data from the Institutions and Elections Project, we coded a dummy variable - Majoritarian Rules - that captures whether the country employs either plurality (first-past-the-post) or majoritarian formulas in the election of legislators. ${ }^{69}$ The use of proportional representation formulas is the reference category. We also include a dummy variable to separate out Mixed Systems for which we have no particular theoretical expectations. ${ }^{70}$ Secondly, we included a variable for the Mean District Magnitude (MDM) in the country where more seats per district is an intrinsic feature of proportional systems.

65 Each news source is individually read and coded by issue based on how the event is described. We retained all events where elections were explicitly mentioned first, second or third as the source of the violence. For a more detailed description of the coding procedure, including search words, see Salehyan et al. (2012). In addition, we have reviewed all events coded as relating to democracy and human rights that occurred within a three-month period before or after the election. A number of additional events with clear relation to the elections were then included in the dependent variables.

66 cf. Daxecker 2012.

67 cf. Straus and Taylor 2012.

68 In Government Violence, we also included election-related events where the government responded with violent repression in the face of a demonstration, strike, riot, etc. In Opposition Violence, we omit events perpetrated by actors within permanent military organizations to exclude violence related to ongoing insurgencies. Robustness tests show similar results when these events are included.

${ }^{69}$ Regan, Frank and Clark 2009. We use the new version of the dataset that is updated through to 2012.

${ }^{70}$ Mixed systems combine PR with either plurality or majority in situations where, for example, a single chamber contains seats selected by different methods or there are two chambers selected by different methods. 
We follow the method of Huber and use the log of this variable because beyond a certain threshold the variable should have no further effect on diffusing the stakes of the electoral contest and on reducing the incentives for violent manipulation. ${ }^{71}$ The MDM variable is from the Database of Political Institutions. ${ }^{72}$ In our data, 2,531 of the observations have first-pastthe-post rules; 1,992 have majority rules; 2,671 had PR rules, and 1,272 have mixed systems. The mean district magnitude for all countries in the study is 9.8 legislative seats.

The choice of electoral institutions is not exogenous to the dynamics of political competition and outcomes. ${ }^{73}$ However, when commenting on recent waves of democratization (which include a large number of African countries), Reilly and Reynolds, for example, have noted that electoral systems rarely seem to have been consciously and deliberately designed to achieve particular societal outcomes, but rather tend to reflect colonial transfers of institutions. ${ }^{74}$ Explaining the choice or development of electoral systems is beyond the scope of this study, but a particular concern for our analysis is whether countries that are particularly predisposed to electoral violence, for example, from having had a history of widespread political violence, are also more likely to have adopted majoritarian institutions. However, studies suggest that where the choice of an electoral system formed part of an elite-negotiated pact to end violent armed conflict, such a choice tended to result in proportional, not majoritarian, electoral rules (e.g., South Africa, Angola, Mozambique and Namibia). ${ }^{75}$ If anything, this should bias against finding support for our main hypothesis.

To examine the second hypothesis, which states that majoritarian institutions are particularly likely to spur electoral violence where large ethno-political groups are excluded from power, we use data from the Ethnic Power Relations (EPR) dataset. ${ }^{76}$ The EPR dataset identifies all politically relevant ethnic groups and measures their members' access to central state power over time. We create a variable for the size of the largest ethno-political group that was excluded from political power, i.e., that was either powerless or discriminated against according to the EPR data. Note that this measure captures group representation within formal political structures and not, for example, the use of violence to exclude groups from popular influence as part of the electoral process.

To examine the third hypothesis, which states that majoritarian institutions increase the likelihood of electoral violence in the context of large economic inequalities, we use a measure of land inequality suggested by Vanhanen. ${ }^{77}$ In Africa's largely agrarian economies, this measure is arguably a more valid indicator of economic inequality than it would be in more developed economies. ${ }^{78}$ Land inequality is measured as the percentage of large-scale farms, i.e., those cultivated by wage workers, relative to small-scale family farms, i.e. 'farms that provide employment for not more than four people, including family members, ... that are cultivated by the holder family itself and ... that are owned by the cultivator family or held in

71 Huber 2012.

72 Beck et al. 2001. The Database of Political Institutions data code the institutions in place as of 1 January every year. Where no electoral system was in place as of this date, but legislative elections were held, we extend the coding for the following year to the preceding electoral period.

${ }^{73}$ For a review of theories of electoral system change, see Benoit 2004.

74 Reilly and Reynolds 2000; see also Norris 1995. In robustness tests, we also included a control for British legal origin to rule out the possibility that British colonial rule is associated with both majoritarian institutions and societal/political legacies that make these countries more prone to electoral violence.

75 Mozaffar and Scarritt 2005.

76 Cederman, Wimmer and Min 2010.

77 Vanhanen 1997, 48; see also Boix 2008.

78 An alternative measure of economic inequality would be the GINI index. However, poor data quality and a lack of coverage, particularly for developing countries, led us to prefer the land inequality measure. 


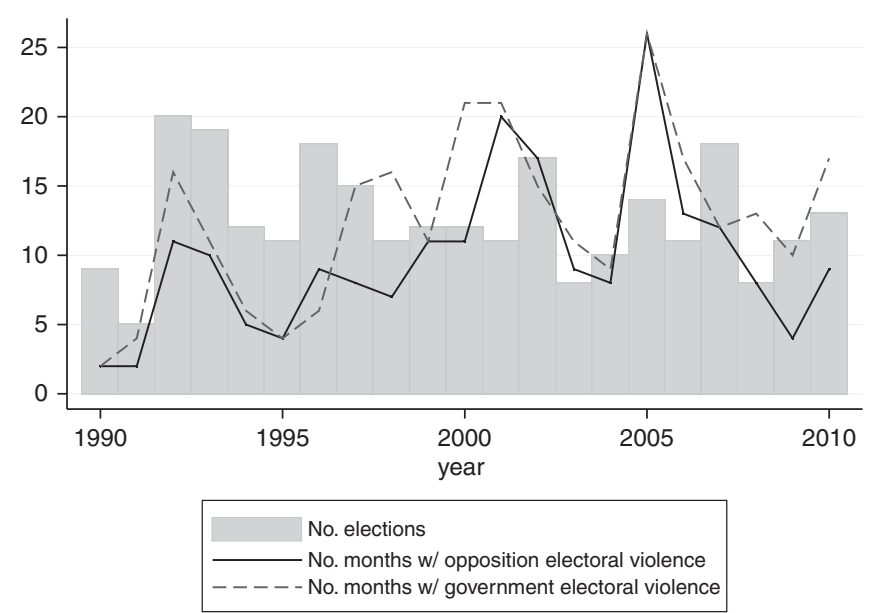

Fig. 1. Elections and electoral violence in Sub-Saharan Africa, 1990-2010

owner-like possession'. ${ }^{79}$ The data are reported by decade resulting in two observation points for our time period. The last observed value is used for in-between years.

We control for the overall level of democracy in each country because electoral violence is considerably less likely to occur within the context of consolidated democratic institutions. ${ }^{80}$ We measure democracy using the Polity scale (which ranges from -10 to +10 ) and include a squared term to capture non-linear effects. ${ }^{81}$ Based on the broader literature on political violence, we control for the size of the country's population and the country's level of economic development. The data for both of these variables come from the National Accounts Main Aggregates Database produced by the United Nations. ${ }^{82}$ To account for temporal dependence, we include a lagged version of the dependent variable. Because the occurrence of electoral violence could be precipitated by on-going large-scale insurgencies, we control for whether an intrastate armed conflict was on-going in the country during the previous month using data from the Uppsala Conflict Data Program. ${ }^{83}$ Additional control variables are discussed in the robustness section.

\section{ANALYSIS}

The trends in electoral violence from 1990 to 2010 are shown in Figure 1. The figure shows the number of months with electoral violence broken down into government and opposition actors alongside the number of monthly observation in which a national election took place each year in the time period studied. Similar to what has been suggested by Straus and Taylor, government or government-affiliated actors are more frequently the perpetrators of electoral violence than actors associated with the opposition. ${ }^{84}$ There are no clear trends in the data over time, although electoral violence seems to have become more frequent up to 2005 and

79 Vanhanen 1997, 48.

80 Arriola and Johnson 2012; Hafner-Burton, Hyde and Jablonski 2014.

81 Marshall, Gurr and Jaggers 2012.

82 United Nations 2009.

83 Gleditsch et al. 2002.

84 Straus and Taylor 2012. 


\begin{tabular}{|c|c|c|c|c|}
\hline & $\begin{array}{l}\text { Opposition } \\
\text { violence } \\
\text { (1) }\end{array}$ & $\begin{array}{l}\text { Opposition } \\
\text { violence } \\
\text { (2) }\end{array}$ & $\begin{array}{c}\text { Government } \\
\text { violence } \\
\text { (3) }\end{array}$ & $\begin{array}{l}\text { Government } \\
\text { violence } \\
\text { (4) }\end{array}$ \\
\hline Majoritarian system & $\begin{array}{l}1.057 \\
(0.387)^{* * * *}\end{array}$ & & $\begin{array}{l}0.714 \\
(0.291)^{* *}\end{array}$ & \\
\hline Mean district magnitude $e_{\log }$ & & $\begin{array}{l}-0.265 \\
(0.089) * * *\end{array}$ & & $\begin{array}{l}-0.200 \\
(0.091)^{* *}\end{array}$ \\
\hline Democracy index $_{\text {lag }}$ & $\begin{array}{c}0.026 \\
(0.019)\end{array}$ & $\begin{array}{c}0.031 \\
(0.026)\end{array}$ & $\begin{array}{r}-0.007 \\
(0.014)\end{array}$ & $\begin{array}{c}-0.021 \\
(0.017)\end{array}$ \\
\hline Democracy index $\mathrm{sq}_{\mathrm{lag}}$ & $\begin{array}{l}-0.012 \\
(0.003) * * *\end{array}$ & $\begin{array}{l}-0.018 \\
(0.006) * * *\end{array}$ & $\begin{array}{l}-0.010 \\
(0.004)^{* *}\end{array}$ & $\begin{array}{c}-0.010 \\
(0.005)^{*}\end{array}$ \\
\hline Population $_{\text {log, lag }}$ & $\begin{array}{l}0.510 \\
(0.082)^{* * * *}\end{array}$ & $\begin{array}{l}0.570 \\
(0.084)^{* * *}\end{array}$ & $\begin{array}{l}0.377 \\
(0.081)^{* * *}\end{array}$ & $\begin{array}{l}0.411 \\
(0.075) * * *\end{array}$ \\
\hline GDP $\mathrm{pc}_{\mathrm{log}, \mathrm{lag}}$ & $\begin{array}{c}0.166 \\
(0.105)\end{array}$ & $\begin{array}{l}0.302 \\
(0.153)^{* *}\end{array}$ & $\begin{array}{c}-0.109 \\
(0.118)\end{array}$ & $\begin{array}{c}-0.058 \\
(0.158)\end{array}$ \\
\hline Armed conflict $t_{t-1}$ & $\begin{array}{l}-1.184 \\
(0.383) * * *\end{array}$ & $\begin{array}{l}-0.904 \\
(0.431)^{* *}\end{array}$ & $\begin{array}{r}-0.676 \\
(0.452)\end{array}$ & $\begin{array}{c}-0.422 \\
(0.517)\end{array}$ \\
\hline Dep. var. $t-1$ & $\begin{array}{l}2.246 \\
(0.318)^{* * *}\end{array}$ & $\begin{array}{l}2.064 \\
(0.381)^{* * *}\end{array}$ & $\begin{array}{l}2.472 \\
(0.227) * * *\end{array}$ & $\begin{array}{l}2.493 \\
(0.239) * * *\end{array}$ \\
\hline Mixed system & $\begin{array}{c}0.560 \\
(0.415)\end{array}$ & & $\begin{array}{l}0.648 \\
(0.316)^{* *}\end{array}$ & \\
\hline Constant & $\begin{array}{l}-13.747 \\
(1.858)^{* * *}\end{array}$ & $\begin{array}{l}-14.397 \\
(1.504) * * *\end{array}$ & $\begin{array}{l}-9.455 \\
(1.359)^{* * *}\end{array}$ & $\begin{array}{l}-9.572 \\
(1.161) * * *\end{array}$ \\
\hline Observations & 8,466 & 7,534 & 8,466 & 7,534 \\
\hline
\end{tabular}

Notes: Robust standard errors clustered by country. ${ }^{*} p<0.1 ; * * p<0.05 ; * * * p<0.01$.

then declined. The peaks in the prevalence of violence do not seem to correspond to the number of elections taking place at that particular time. ${ }^{85}$

Our argument suggests that majoritarian electoral formulas and smaller electoral districts are associated with a higher risk of electoral violence in non-consolidated democracies. Because our dependent variable is dichotomous, we evaluate this argument using logit models with robust standard errors clustered by country. The results are reported in Table 1 . As can be seen from Model 1, the electoral system has a significant impact on the risk of opposition electoral violence, and the coefficient for the majoritarian formula is positive and significant at the 99 per cent confidence level. The predicted probability of opposition violence in a given month is 2.1 per cent in a majoritarian system compared to 0.8 per cent in any form of PR system. ${ }^{86}$ In Model 2 , the negative and significant coefficient for MDM supports the expectation that more legislative seats from each constituency lower the barrier for representation, reduce the stakes of the electoral contest, and create more opportunities for victory. Moving from the 10th to the 90th percentile for the MDM variable, the predicted risk of opposition electoral violence more than halved from 1.9 to 0.7 per cent in any given country-month. ${ }^{87}$

${ }^{85}$ For descriptive statistics on electoral violence by country, see the online appendix, Table A1.

86 All substantive effects were calculated using Clarify (Tomz, Wittenberg and King 2003) with all continuous control variables held at their mean values and the armed conflict and the lagged dependent variables set to 0 .

87 Although the decrease in the risk of electoral violence is high in relative terms, the reduction in absolute terms might seem negligent. This reflects the fact that electoral violence is a relatively rare phenomenon and that the baseline risk for any given country during any given month is quite low (see Straus and Taylor 2012, 23). 
In Models 3 and 4, we examine the influence of the electoral system on government electoral violence. The positive and significant coefficient for majoritarian electoral system supports our hypothesis. Governments and government-affiliated agents are more likely to engage in violent electoral manipulation in countries with majoritarian formulas, and the probability of violence is more than twice as high (2.3 per cent) compared to PR systems (1.1 per cent). The coefficient for MDM is negative, as expected, and significant at the 95 per cent confidence level. Systems with larger electoral districts have a lower risk of government electoral violence. Moving from the 10th to the 90th percentile on the district magnitude variable reduces the risk of government electoral violence from 2.2 to 1.1 per cent. These results are consistent with our argument that electoral institutions that induce a perception of the electoral contest as zero-sum increase the risk of electoral violence in Africa's electoral regimes. Overall, our results testify to relationships that are substantively important and statistically significant.

We have conducted a number of robustness tests on the above results. ${ }^{88}$ Our dichotomous variable denoting simply whether an incidence of electoral violence occurred that month or not masks substantive variation across countries over time in terms of the level of violence. As a first robustness test we have, therefore, used the number of events in the country-month as an alternative dependent variable and estimated a negative binomial regression model. With this specification, the relationship between majoritarian rules and government electoral violence just misses significance at the 95 per cent level. All other results remain unaltered. Secondly, we have ensured that the results are virtually identical if we also include violent events perpetrated by organized militant groups in the opposition actor category. Thirdly, the results do not change if we include a control for previous electoral violence by the government in the analysis of opposition actor violence and vice versa. Fourthly, our results do not change if we include a control for the quality of governance (i.e., an overall assessment of corruption, law and order, and quality of the bureaucracy) as an indicator of the overall prospects for conducting highintegrity elections. ${ }^{89}$ In addition, the results are robust to the inclusion of year dummy variables suggesting that no time-specific trends are driving our results. We also re-run all models in Table 1 dropping one country at a time to ensure that no individual country is driving our results. The only result that is somewhat sensitive is the impact of MDM on government electoral violence, which for some countries drops to 90 per cent significance.

Looking at the other covariates in Table 1, our results corroborate the importance of democratic institutions more generally. These results suggest that hybrid regimes, which mix democratic and authoritarian institutions, are more susceptible to electoral violence by opposition actors compared to the relatively more consolidated democracies and autocracies found within this sample. For government actors, there seems to be a more linear relationship where more liberal institutions constrain the use of electoral violence. In all four models, the democracy index and its squared term are jointly significant at the 95 per cent level. More populous countries generally have a higher risk of electoral violence, but the impact of economic development is inconsistent across the models. In some models we find that on-going civil wars decrease the likelihood of electoral violence by the opposition. Finally, we find that electoral violence breeds renewed violence and that the occurrence of electoral violence the previous month increases the risk of similar violence in subsequent months.

Our main model includes only a limited number of control variables because we assume that electoral institutions - although an intrinsic part of the bargaining between key political actors at

88 All models are available in the online appendix.

89 The data were from the International Country Risk Guide, and the variable was taken from the Quality of Government dataset (Teorell et al. 2011). 
the time the institutions were put into place - rarely change in response to more election-specific dynamics. As additional tests, however, we have run our models with a number of variables related more specifically to the dynamics of the electoral contest. For this analysis, we retain only election-months and six months before and six months after an election to avoid making questionable assumptions about the influence of election-specific variables for the months in between elections. First, we include a variable noting whether the incumbent was running or not based on the assumption that elections have higher stakes when the executive seeks re-election. ${ }^{90}$ Secondly, we control for the presence of election monitors during the elections as a potential determinant of opportunities for violent electoral manipulation. ${ }^{91}$ Thirdly, we control for reports of suspected electoral fraud. ${ }^{92}$ Finally, we include a variable that marks the elections as competitive if opposition was allowed, more than one party was legal, and there was a choice of candidates at the ballot. ${ }^{93}$ All variables are from the NELDA dataset. ${ }^{94}$ The results are reported in Table 2 . The only result that is affected by these alternative case selection criteria and alternative controls is the effect of district magnitude on the risk of opposition violence, which drops to 90 per cent significance. The results reported in Table 2 include both presidential and legislative elections. However, the results for electoral institutions remain virtually the same if we focus on legislative elections only. ${ }^{95}$ Thus, we conclude that there is a strong residual effect of electoral institutions even when controlling for election-specific dynamics.

Next, we evaluate our two hypotheses regarding the conditional effects of electoral institutions. We examine the argument that the effect of majoritarian institutions will be particularly profound where large ethno-political groups are excluded from power by including an interaction term between the size of the largest excluded ethno-political group and our electoral system variables. These results are reported in Models 1-4 in Table 3. With the introduction of interaction terms, the model parameters per se are of limited interest. ${ }^{96}$ Figure 2 , therefore, presents these results in a more meaningful manner by displaying the marginal effects of a change in electoral institutions across the range of values for politically excluded group size along with the 95 per cent confidence intervals shown in grey. ${ }^{97}$

We start by focusing on opposition electoral violence. As seen in Figure 2a, the conflictinducing effect of majoritarian formulas increases with the size of the largest excluded group. In a country with no excluded ethno-political group, there is no statistically significant effect of a change from PR to majoritarian rules. For a country where the largest excluded ethno-political groups constitutes 44 per cent of the population (i.e., at the 95 th percentile), a change from PR to majoritarian rules is associated with an increased risk of opposition violence of about 4 per cent. The difference-in-differences between these two scenarios is statistically significant at the 95 per cent level suggesting a clear interaction effect.

The effect of district magnitude shown in Figure $2 b$ is similar, and the conflict-reducing effect of larger district magnitudes increases with the size of the largest ethno-political groups. Increasing district magnitude by one unit (on the logged variable) reduces the risk of election

90 This variable applies to elections to leadership positions only.

91 Daxecker 2012.

92 Hafner-Burton, Hyde and Jablonski 2014.

93 Hyde and Marinov 2012.

94 Hyde and Marinov 2012.

95 See Table A8 in the online appendix.

96 Brambor, Clark and Golder 2006.

97 All continuous control variables are held at their mean values, armed conflict is set to 0, and the lagged dependent variable is set to 0 . 
TABLE 2 Electoral Systems, Electoral Dynamics, and Electoral Violence

\begin{tabular}{|c|c|c|c|c|}
\hline & $\begin{array}{l}\text { Opposition } \\
\text { violence } \\
\text { (1) }\end{array}$ & $\begin{array}{l}\text { Opposition } \\
\text { violence } \\
\text { (2) }\end{array}$ & $\begin{array}{c}\text { Government } \\
\text { violence } \\
\text { (3) }\end{array}$ & $\begin{array}{l}\text { Government } \\
\text { violence } \\
\text { (4) }\end{array}$ \\
\hline Majoritarian system & $\begin{array}{l}0.960 \\
(0.360)^{* * *}\end{array}$ & & $\begin{array}{l}0.654 \\
(0.297)^{* *}\end{array}$ & \\
\hline Mean district magn $_{\log }$ & & $\begin{array}{c}-0.191 \\
(0.100)^{*}\end{array}$ & & $\begin{array}{l}-0.249 \\
(0.103) * *\end{array}$ \\
\hline Allegations of fraud & $\begin{array}{l}0.852 \\
(0.277)^{* * *}\end{array}$ & $\begin{array}{c}0.893 \\
(0.299) * * *\end{array}$ & $\begin{array}{l}0.741 \\
(0.203)^{* * *}\end{array}$ & $\begin{array}{l}0.751 \\
(0.212)^{* * *}\end{array}$ \\
\hline Competitiveness & $\begin{array}{l}2.240 \\
(0.665)^{* * *}\end{array}$ & $\begin{array}{l}1.960 \\
(0.665)^{* * *}\end{array}$ & $\begin{array}{r}-0.120 \\
(0.395)\end{array}$ & $\begin{array}{r}-0.307 \\
(0.389)\end{array}$ \\
\hline Incumbent running & $\begin{array}{c}-0.050 \\
(0.210)\end{array}$ & $\begin{array}{c}0.104 \\
(0.217)\end{array}$ & $\begin{array}{c}0.225 \\
(0.170)\end{array}$ & $\begin{array}{c}0.283 \\
(0.168)^{*}\end{array}$ \\
\hline International monitors & $\begin{array}{c}0.004 \\
(0.371)\end{array}$ & $\begin{array}{r}-0.025 \\
(0.349)\end{array}$ & $\begin{array}{c}0.192 \\
(0.377)\end{array}$ & $\begin{array}{c}0.053 \\
(0.393)\end{array}$ \\
\hline Democracy index $_{\text {lag }}$ & $\begin{array}{l}0.043 \\
(0.019)^{* *}\end{array}$ & $\begin{array}{l}0.066 \\
(0.025) * * *\end{array}$ & $\begin{array}{c}0.013 \\
(0.015)\end{array}$ & $\begin{array}{c}0.006 \\
(0.018)\end{array}$ \\
\hline Democracy index sq lag & $\begin{array}{l}-0.011 \\
(0.005) * *\end{array}$ & $\begin{array}{l}-0.020 \\
(0.006) * * *\end{array}$ & $\begin{array}{l}-0.010 \\
(0.004)^{* *}\end{array}$ & $\begin{array}{c}-0.009 \\
(0.005)^{*}\end{array}$ \\
\hline Population, lag log & $\begin{array}{c}0.248 \\
(0.129)^{*}\end{array}$ & $\begin{array}{l}0.316 \\
(0.114)^{* * *}\end{array}$ & $\begin{array}{l}0.242 \\
(0.095)^{* *}\end{array}$ & $\begin{array}{l}0.263 \\
(0.083) * * *\end{array}$ \\
\hline GDP pc ${ }_{\text {lag }}, \log$ & $\begin{array}{c}0.080 \\
(0.134)\end{array}$ & $\begin{array}{c}0.296 \\
(0.158)^{*}\end{array}$ & $\begin{array}{c}-0.075 \\
(0.131)\end{array}$ & $\begin{array}{c}0.081 \\
(0.170)\end{array}$ \\
\hline Armed conflict lag & $\begin{array}{r}-0.590 \\
(0.576)\end{array}$ & $\begin{array}{c}-0.138 \\
(0.628)\end{array}$ & $\begin{array}{c}-0.409 \\
(0.474)\end{array}$ & $\begin{array}{c}0.127 \\
(0.485)\end{array}$ \\
\hline Dep. var. $t-1$ & $\begin{array}{l}1.601 \\
(0.285)^{* * *}\end{array}$ & $\begin{array}{l}1.528 \\
(0.287)^{* * *}\end{array}$ & $\begin{array}{l}1.626 \\
(0.249)^{* * *}\end{array}$ & $\begin{array}{l}1.730 \\
(0.255)^{* * *}\end{array}$ \\
\hline Mixed system & $\begin{array}{c}0.451 \\
(0.395)\end{array}$ & & $\begin{array}{c}0.592 \\
(0.328)^{*}\end{array}$ & \\
\hline Constant & $\begin{array}{l}-10.224 \\
(2.749)^{* * *}\end{array}$ & $\begin{array}{l}-11.491 \\
\quad(2.302)^{* * *}\end{array}$ & $\begin{array}{l}-6.722 \\
(1.853)^{* * *}\end{array}$ & $\begin{array}{l}-7.171 \\
(1.691)^{* * *}\end{array}$ \\
\hline$N$ & 2,337 & 2,149 & 2,337 & 2,149 \\
\hline
\end{tabular}

Notes: Robust standard errors clustered by country. ${ }^{*} p<0.1 ; * * p<0.05 ; * * * p<0.01$.

violence by 0.5 per cent when there is no excluded group, but by 1 per cent when the largest excluded groups constitutes 44 per cent of the population. Again, the difference-in-differences is significant at the 95 per cent confidence level.

Our results suggest a similar pattern with regard to the risk of government violence (Figures $2 \mathrm{c}$ and $2 \mathrm{~d}$ ). The conflict-inducing effect of going from PR to majoritarian formulas is positive and becomes stronger as the size of the excluded ethno-political group increases. The marginal effect is 0.2 per cent when there are no excluded groups and 3.8 per cent when the largest excluded group constitutes 44 per cent of the population, and the difference-indifferences is significant at the 95 per cent level. The conflict-dampening effect of larger electoral districts is also negative across all values of the ethno-political exclusion variable. However, the curve is almost flat and the test statistics shows no evidence of a significant interaction effect.

We next focus on the interaction effect between electoral institutions and different levels of land inequality. The results are reported for Models 5-8 in Table 3 and are graphed in Figure 3. 
тавце 3 Electoral Systems, Societal Cleavages and Electoral Violence

\begin{tabular}{|c|c|c|c|c|c|c|c|c|}
\hline & $\begin{array}{l}\text { Opposition } \\
\text { violence } \\
\text { (1) }\end{array}$ & $\begin{array}{l}\text { Opposition } \\
\text { violence } \\
\text { (2) }\end{array}$ & $\begin{array}{c}\text { Government } \\
\text { violence } \\
\text { (3) }\end{array}$ & $\begin{array}{l}\text { Government } \\
\text { violence } \\
\text { (4) }\end{array}$ & $\begin{array}{l}\text { Opposition } \\
\text { violence } \\
(5)\end{array}$ & $\begin{array}{l}\text { Opposition } \\
\text { violence } \\
(6)\end{array}$ & $\begin{array}{c}\text { Government } \\
\text { violence } \\
\text { (7) }\end{array}$ & $\begin{array}{c}\text { Government } \\
\text { violence } \\
\text { (8) }\end{array}$ \\
\hline Majoritarian system & $\begin{array}{c}0.636 \\
(0.439)\end{array}$ & & $\begin{array}{l}0.892 \\
(0.296)^{* * * *}\end{array}$ & & $\begin{array}{c}-0.906 \\
(1.254)\end{array}$ & & $\begin{array}{l}-1.831 \\
(0.913)^{* *}\end{array}$ & \\
\hline Mean district magn $_{\log }$ & & $\begin{array}{c}-0.138 \\
(0.101)\end{array}$ & & $\begin{array}{l}-0.293 \\
(0.112)^{* * *}\end{array}$ & & $\begin{array}{r}-0.317 \\
(0.375)\end{array}$ & & $\begin{array}{c}0.456 \\
(0.461)\end{array}$ \\
\hline Ethnic exclusion & $\begin{array}{l}-2.730 \\
(1.609)^{*}\end{array}$ & $\begin{array}{l}1.524 \\
(0.736)^{* *}\end{array}$ & $\begin{array}{c}0.371 \\
(0.786)\end{array}$ & $\begin{array}{l}1.240 \\
(0.603)^{* *}\end{array}$ & & & & \\
\hline Maj.*Exclusion & $\begin{array}{l}4.864 \\
(1.761)^{* * *}\end{array}$ & & $\begin{array}{l}1.873 \\
(1.206)\end{array}$ & & & & & \\
\hline MDM* Exclusion & & $\begin{array}{l}-1.110 \\
(0.442)^{* *}\end{array}$ & & $\begin{array}{c}0.010 \\
(0.337)\end{array}$ & & & & \\
\hline Land inequality & & & & & $\begin{array}{r}-1.533 \\
(1.493)\end{array}$ & $\begin{array}{c}0.611 \\
(1.190)\end{array}$ & $\begin{array}{c}-2.012 \\
(1.309)\end{array}$ & $\begin{array}{l}2.076 \\
(1.086)^{*}\end{array}$ \\
\hline Maj.*Inequality & & & & & $\begin{array}{l}3.787 \\
(1.856)^{* *}\end{array}$ & & $\begin{array}{l}5.062 \\
(1.541) * * *\end{array}$ & \\
\hline MDM*Inequality & & & & & & $\begin{array}{c}0.047 \\
(0.579)\end{array}$ & & $\begin{array}{r}-1.194 \\
(0.785)\end{array}$ \\
\hline Democracy $_{\text {lag }}$ & $\begin{array}{l}0.046 \\
(0.021)^{* *}\end{array}$ & $\begin{array}{l}0.049 \\
(0.025)^{*}\end{array}$ & $\begin{array}{c}0.021 \\
(0.016)\end{array}$ & $\begin{array}{c}0.002 \\
(0.019)\end{array}$ & $\begin{array}{l}0.039 \\
(0.021)^{*}\end{array}$ & $\begin{array}{c}0.033 \\
(0.027)\end{array}$ & $\begin{array}{c}0.010 \\
(0.015)\end{array}$ & $\begin{array}{c}-0.010 \\
(0.018)\end{array}$ \\
\hline Democracy sq lag & $\begin{array}{l}-0.014 \\
(0.004)^{* * *}\end{array}$ & $\begin{array}{l}-0.021 \\
(0.006)^{* * *}\end{array}$ & $\begin{array}{l}-0.010 \\
(0.004)^{* *}\end{array}$ & $\begin{array}{l}-0.010 \\
(0.006)^{*}\end{array}$ & $\begin{array}{l}-0.013 \\
(0.004)^{* * *}\end{array}$ & $\begin{array}{l}-0.020 \\
(0.006) * * *\end{array}$ & $\begin{array}{l}-0.012 \\
(0.005)^{* *}\end{array}$ & $\begin{array}{l}-0.010 \\
(0.006) *\end{array}$ \\
\hline Population ${ }_{\text {lag,log }}$ & $\begin{array}{l}0.519 \\
(0.087)^{* * *}\end{array}$ & $\begin{array}{l}0.591 \\
(0.084)^{* * * *}\end{array}$ & $\begin{array}{l}0.351 \\
(0.086)^{* * *}\end{array}$ & $\begin{array}{l}0.403 \\
(0.077)^{* * * *}\end{array}$ & $\begin{array}{l}0.556 \\
(0.084)^{* * * *}\end{array}$ & $\begin{array}{l}0.567 \\
(0.095)^{* * * *}\end{array}$ & $\begin{array}{l}0.418 \\
(0.092) * * *\end{array}$ & $\begin{array}{l}0.482 \\
(0.087)^{* * *}\end{array}$ \\
\hline GDP pc ${ }_{1 a g}, \log$ & $\begin{array}{c}0.165 \\
(0.127)\end{array}$ & $\begin{array}{c}0.259 \\
(0.164)\end{array}$ & $\begin{array}{r}-0.082 \\
(0.135)\end{array}$ & $\begin{array}{c}0.027 \\
(0.176)\end{array}$ & $\begin{array}{l}0.261 \\
(0.116) * *\end{array}$ & $\begin{array}{c}0.283 \\
(0.175)\end{array}$ & $\begin{array}{c}-0.017 \\
(0.151)\end{array}$ & $\begin{array}{c}-0.052 \\
(0.167)\end{array}$ \\
\hline Armed conflict $t_{-1}$ & $\begin{array}{l}-1.025 \\
(0.398)^{* * *}\end{array}$ & $\begin{array}{c}-0.692 \\
(0.448)\end{array}$ & $\begin{array}{l}-1.206 \\
(0.407)^{* * * *}\end{array}$ & $\begin{array}{l}-0.979 \\
(0.427)^{* *}\end{array}$ & $\begin{array}{l}-1.172 \\
(0.374)^{* * *}\end{array}$ & $\begin{array}{c}-0.872 \\
(0.452)^{*}\end{array}$ & $\begin{array}{c}-0.647 \\
(0.458)\end{array}$ & $\begin{array}{c}-0.438 \\
(0.502)\end{array}$ \\
\hline Dep. var. $t-1$ & $\begin{array}{l}2.094 \\
(0.314)^{* * *}\end{array}$ & $\begin{array}{l}1.941 \\
(0.376)^{* * *}\end{array}$ & $\begin{array}{l}2.288 \\
(0.229)^{* * *}\end{array}$ & $\begin{array}{l}2.334 \\
(0.231)^{* * * *}\end{array}$ & $\begin{array}{l}2.212 \\
(0.316) * * *\end{array}$ & $\begin{array}{l}2.058 \\
(0.381)^{* * * *}\end{array}$ & $\begin{array}{l}2.398 \\
(0.245)^{* * *}\end{array}$ & $\begin{array}{l}2.445 \\
(0.254)^{* * * *}\end{array}$ \\
\hline Mixed system & $\begin{array}{c}0.398 \\
(0.420)\end{array}$ & & $\begin{array}{l}0.918 \\
(0.303)^{* * *}\end{array}$ & & $\begin{array}{c}0.409 \\
(0.535)\end{array}$ & & $\begin{array}{c}0.536 \\
(0.378)\end{array}$ & \\
\hline Constant & $\begin{aligned}- & 13.565 \\
& (1.807)^{* * * *}\end{aligned}$ & $\begin{aligned}- & 14.526 \\
& (1.497)^{* * * *}\end{aligned}$ & $\begin{array}{l}-9.503 \\
(1.436)^{* * *}\end{array}$ & $\begin{array}{l}-10.021 \\
(1.239) * * *\end{array}$ & $\begin{array}{l}-14.200 \\
(1.920)^{* * *}\end{array}$ & $\begin{aligned}- & 14.474 \\
& (2.156)^{* * *}\end{aligned}$ & $\begin{array}{l}-9.612 \\
(1.567)^{* * *}\end{array}$ & $\begin{aligned}- & 11.818 \\
& (1.763)^{* * * *}\end{aligned}$ \\
\hline$N$ & 7,782 & 6,862 & 7,782 & 6,862 & 8,466 & 7,534 & 8,466 & 7,534 \\
\hline
\end{tabular}

Notes: Robust standard errors clustered by country. ${ }^{*} p<0.1 ;{ }^{*} p<0.05 ; * * * p<0.01$. 

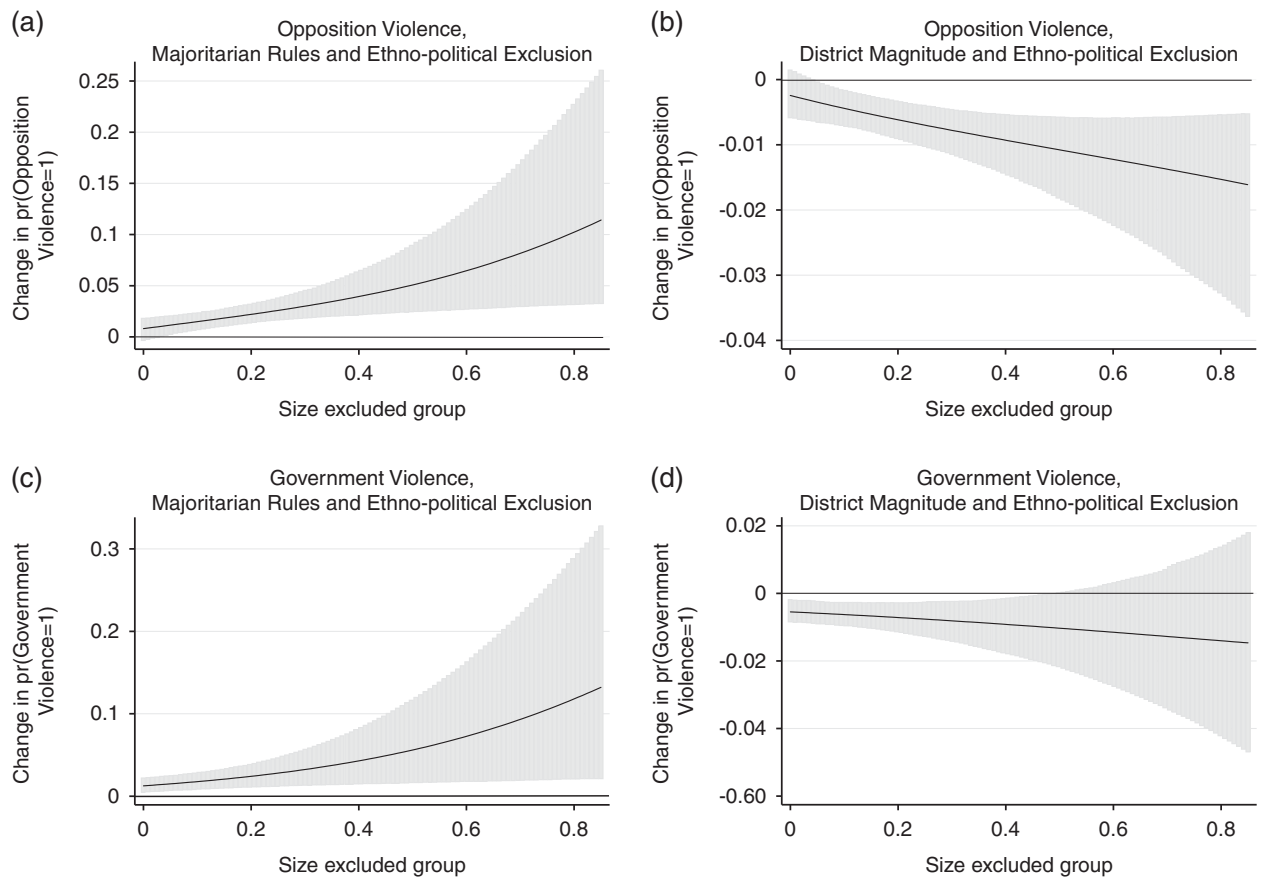

Fig. 2. Electoral systems and ethno-political exclusion

Note: Figures show the change in the predicted probability of electoral violence when going from proportional to majoritarian electoral rules (Figs $3 \mathrm{a}$ and $3 \mathrm{c}$ ) and when increasing mean district magnitude (log transformed) with one unit (Figs 3b and 3d) at different levels of ethno-political exclusion. Ethno-political exclusion is measured as the size of the largest excluded ethno-political group relative to the country population. Shaded area shows the 95 per cent confidence intervals.

Large economic inequalities increase the risk that majoritarian formulas lead to opposition violence (Figure $3 \mathrm{a}$ ). For a country in the 5 th percentile on the land inequality measure (i.e., with 40 per cent large-holding farms), the effect of going from PR to majoritarian rules increases the risk of violence by 0.2 per cent. For a country in the 95th percentile (with 74 per cent largeholding farms), the corresponding marginal effect is 2.6 per cent. The difference-in-differences between these scenarios is statistically significant at the 95 per cent level. For the MDM variable (Figure 3b) there is no evidence of a significant interaction effect.

For government violence, the conflict-inducing impact of economic inequality under majoritarian institutions applies to both electoral formulas and district magnitude. When we compare countries at the 5th and 95th percentiles on land inequality, we can see that the marginal effect of going from PR to majoritarian rules on the risk of government violence increases from close to 0 to 2.5 per cent. The difference-in-differences is significant at the 95 per cent level. In addition, district magnitude becomes increasingly important at higher levels of land inequality. A one-unit increase in district magnitude (logged) does not have a statistically discernable effect for a country at the 5th percentile on the land inequality variable. At the 95th percentile, however, the violence-reducing effect of district magnitude is 0.7 per cent and is statistically significant at the 95 per cent level. Thus, majoritarian institutions seem to motivate governments to use election violence in countries where wealth is narrowly concentrated. 
(a)

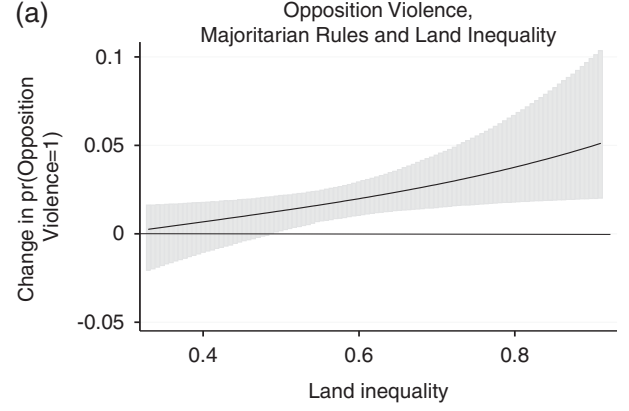

(c)

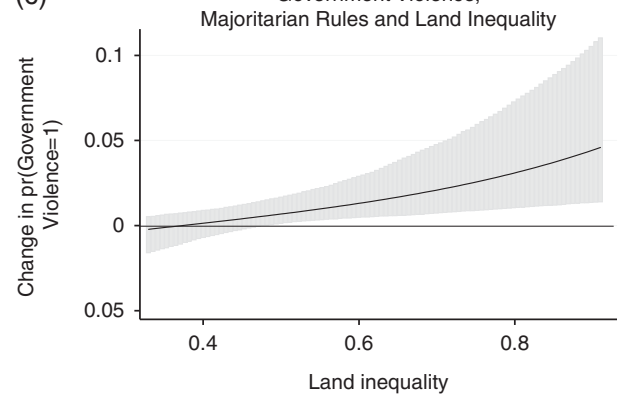

(b)

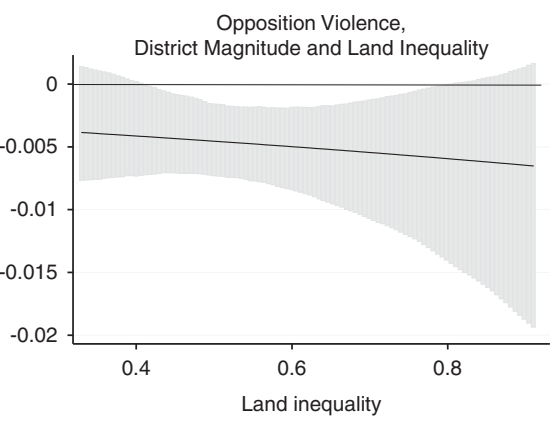

(d)

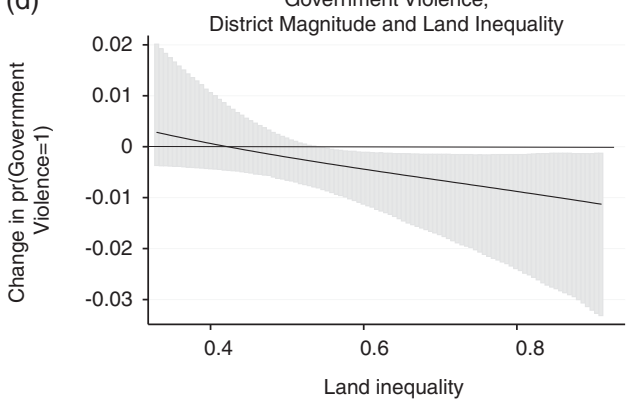

Fig. 3. Electoral systems and land inequality

Note: Figures show the change in the predicted probability of electoral violence when going from proportional to majoritarian electoral rules (Figs 3a and 3c) and when increasing mean district magnitude (log transformed) with one unit (Figs 3b and 3d) for different levels of land inequality. Land inequality is measured as the share of large-scale farms (as opposed to family farms). Shaded area shows the 95 per cent confidence intervals.

\section{CONCLUSIONS}

This article provides the first large-scale study on the influence of electoral institutions on the risk of electoral violence. Focusing on the electoral regimes of Sub-Saharan Africa, we find that electoral institutions are important for shaping the incentives for governments and opposition alike to engage in electoral violence. PR systems and a greater number of legislative seats per electoral district significantly reduce the risk that actors will engage in violent electoral strategies. PR electoral institutions are particularly important for mitigating the risk of electoral violence where large ethno-political groups are excluded from power. They also become important in the presence of large wealth inequalities in determining the likelihood that political actors will use violent electoral strategies.

This study represents a first step in examining the role of electoral institutions in augmenting the incentives to manipulate electoral contests by means of violence. Many other institutional choices might be of consequence beyond those we have been able to address in this article, including the independence and powers of electoral monitoring bodies, the degree and forms of political decentralization, and the more specific configurations of different sets of electoral rules. These represent interesting avenues for future research. Aspects of the argument presented here could also be probed further by using more fine-grained data on, for example, party system composition and voting patterns at the sub-national level.

This study has focused on electoral violence in Sub-Saharan Africa, so a reasonable question to ask is whether our theoretical arguments and findings are applicable beyond this region. 
Our argument is specifically embedded in the realities of African politics, including pervasive clientelism, the political relevance of ethnic groups, and the weakly institutionalized opposition, all of which point to the importance of informal institutions for determining the influence of formal institutions. As such, we believe that the type of electoral institutions described here have more profound implications than would be the case in a context of more consolidated democratic regimes. However, Sub-Saharan Africa is not unique in facing the challenges of electoral politics within a context of pervasive corruption, high social fragmentation, and party competition stymied by strong authoritarian legacies. The emerging electoral regimes in the Middle East are cases in point. Our findings emphasize that if a country wishes to facilitate democratic consolidation and avoid electoral violence it is important to craft electoral institutions that reduce the stakes of political competition, diffuse the spoils of political power, and lower the threshold for the opposition to gain political representation.

\section{REFERENCES}

Arriola, Leonardo, and Chelsea Johnson. 2012. Insurgents, Institutions and Post-Conflict Elections. Unpublished manuscript, University of California, Berkeley.

Barkan, Joel D. 1995. Elections in Agrarian Societies. Journal of Democracy 6 (4):106-16.

Bates, Robert H. 1983. Modernization, Ethnic Competition and the Rationality of Politics in Contemporary Africa. Pp. 152-71 in State Versus Ethnic Claims: African Policy Dilemmas, edited by Donald Rotchild and Victor Olorunsola. Boulder, Colo.: Westview Press.

Beck, Thorsten, George Clarke, Alberto Groff, Philip Keefer, and Patrick Walsh. 2001. New Tools in Comparative Political Economy: The Database of Political Institutions. World Bank Economic Review 15 (1):165-76.

Bekoe, Dorina, ed. 2012. Voting In Fear: Electoral Violence in Sub-Saharan Africa. Washington, D.C.: United States Institute of Peace.

Benoit, Kenneth. 2004. Models of Electoral System Change. Electoral Studies 23:363-89.

Birch, Sarah. 2005. Single-Member District Electoral Systems and Democratic Transition. Electoral Studies 24:281-301.

- 2007. Electoral Systems and Electoral Misconduct. Comparative Political Studies 40 (12): $1533-56$.

Birnir, Johanna. 2007. Ethnicity and Electoral Politics. Cambridge: Cambridge University Press.

Bogaards, Matthijs. 2000. Crafting Competitive Party Systems: Electoral Laws and the Opposition in Africa. Democratization 7 (4):163-90. Boone, Catherine. 1990. The Making of a Rentier Class: Wealth Accumulation and Political Control in Senegal. Journal of Development Studies 26 (3): 425-49.

Boix, Carles. 2003. Democracy and Redistribution. New York: Cambridge University Press.

- 2008. Economic Roots of Civil Wars and Revolutions in the Contemporary World. World Politics 60 (3):390-437.

Boone, Catherine. 2009. Electoral Populism where Property Rights Are Weak: Land Politics in Contemporary Sub-Saharan Africa. Comparative Politics 41 (2):183-201.

- 2011. Politically Allocated Land Rights and the Geography of Electoral Violence: The Case of Kenya in the 1990s. Comparative Political Studies 44 (10):1311-42.

Boone, Catherine, and Norma Kriger. 2012. Land Patronage and Elections: Winners and Losers in Zimbabwe and Côte d'Ivoire. Pp. 75-117 in Voting in Fear: Electoral Violence in Sub-Saharan Africa, edited by Dorina Bekoe. Washington, D.C.: United States Institute of Peace.

Brambor, Tomas, William Clark, and Matt Golder. 2006. Understanding Interaction Models: Improving Empirical Analyses. Political Analysis 14:63-82.

Brancati, Dawn, and Jack Snyder. 2013. Time to Kill: The Impact of Election Timing on Post-Conflict Stability. Journal of Conflict Resolution 57 (5):822-53. 
Bratton, Michael. 2007. The Democracy Barometers I: Formal versus Informal Institutions in Africa. Journal of Democracy 18 (3):81-95.

2008. Vote Buying and Violence in Nigerian Election Campaigns. Electoral Studies 27:621-32.

Cho, Wonbin. 2010. Citizens' Perception of Government Responsiveness in Africa: Do Electoral Systems and Ethnic Diversity Matter? Comparative Political Studies 43 (12):1650-74.

Cederman, Lars Erik, Kristian Skrede Gleditsch, and Simon Hug. 2012. Elections and Ethnic Civil War. Comparative Political Studies 46 (3):387-417.

Cederman, Lars-Erik, Andreas Wimmer, and Brian Min. 2010. Why Do Ethnic Groups Rebel? New Data and Analysis. World Politics 62:87-119.

Cohen, Frank. 1997. Proportional Versus Majoritarian Ethnic Conflict Management in Democracies. Comparative Political Studies 30 (5):607-30.

Collier, Paul, and Pedro Vicente. 2012. Violence, Bribery, and Fraud: The Political Economy of Elections in Sub-Saharan Africa. Public Choice 153:117-47.

Dahl, Robert A. 1971. Polyarchy: Participation and Opposition. New Haven, Conn.: Yale University Press.

Daxecker, Ursula E. 2012. Exposing Cheating: International Election Monitoring, Fraud, and PostElection Violence in Africa. Journal of Peace Research 49 (4):503-16.

Diamond, Larry. 2008. The Rule of Law versus the Big Man. Journal of Democracy 19 (2):138-49.

Dunning, Thad. 2011. Fighting and Voting: Violent Conflict and Electoral Politics. Journal of Conflict Resolution 55 (June):327-39.

Fearon, James D. 2006. Ethnic Mobilization And Ethnic Violence. In B. R. Weingast and D. Wittman (Eds.), Oxford Handbook of Political Economy (852-68). Oxford: Oxford University Press.

Flores, Thomas, and Irfaan Noourdin. 2012. The Effect of Elections on Post-Conflict Peace and Reconstruction. Journal of Politics 74 (2):558-70.

Gandhi, Jennifer and Ellen Lust-Oskar. 2009. Elections Under Authoritarianism. Annual Review of Political Science 2009 (12):403-22.

Gleditsch, Nils Petter, Peter Wallensteen, Mikael Eriksson, Margareta Sollenberg, and Håvard Strand. 2002. Armed Conflict 1946-2001: A New Dataset. Journal of Peace Research 39 (5):615-37.

Hafner-Burton, Emilie, Susan Hyde, and Ryan S. Jablonski. 2013. Surviving Elections: Violence and Leader Tenure. Unpublished manuscript. Available from http://ssrn.com/abstract=1975026. Accessed 1 March 2014.

- 2014. When Do Governments Resort to Election Violence? British Journal of Political Science 44 (1):149-79.

Helmke, Gretchen, and Steven Levitsky. 2004. Informal Institutions and Comparative Politics: A Research Agenda. Perspectives on Politics 2 (4):725-40.

Höglund, Kristine. 2009. Electoral Violence in Conflict-Ridden Societies: Concepts, Causes, and Consequences. Terrorism and Political Violence 21 (3):412-27.

Horowitz, Donald. 1985. Ethnic Groups in Conflict. Berkeley: University of California Press.

—. 2001. The Deadly Ethnic Riot. Berkeley: University of California Press.

- 2003. Electoral Systems: A Primer for Decision Makers. Journal of Democracy 14 (4):115-27.

Huber, John D. 2012. Measuring Ethnic Voting: Do Proportional Electoral Laws Politicize Ethnicity? American Journal of Political Science 56 (4):986-1001.

Huntington, Samuel P. 1991. The Third Wave: Democratization in the Late Twentieth Century. Norman: University of Oklahoma Press.

Hyde, Susan, and Nikolay Marinov. 2012. Which Elections Can Be Lost? Political Analysis 20 (2): 191-210.

Hyden, Goran. 2006. African Politics in Comparative Perspective. New York: Cambridge University Press.

Kirschke, Linda. 2000. Informal Repression, Zero-sum Politics and Late Third Wave Transitions. Journal of Modern African Studies 38 (3):383-405.

Klopp, Jaqueline, and Elke Zuern. 2007. The Politics of Violence in Democratization Lessons from Kenya and South Africa. Comparative Politics 39 (2):127-46.

Knutsen, Carl-Henrik. 2011. Which Democracies Prosper? Electoral Rules, Form of Government and Economic Growth. Electoral Studies 30:83-90. 
Lardeyret, Guy. 1991. The Problem with PR. Journal of Democracy 2:30-35.

Lehoucq, Fabrice. 2003. Electoral Fraud: Causes, Types and Consequences. Annual Review of Political Science 6:233-56.

Lijphart, Arend. 1977. Democracy in Plural Societies: A Comparative Exploration. New Haven, Conn.: Yale University Press.

2004. Constitutional Design for Divided Societies. Journal of Democracy 15 (2):96-109.

Lindberg, Staffan. 2003. 'It's Our Time to Chop': Do Elections in Africa Feed Neo-Patrimonialism Rather Than Counteract it? Democratization 14 (2):121-40.

2005. Consequences of Electoral Systems in Africa: A Preliminary Inquiry. Electoral Studies 24:41-64.

Linebarger, Chris, and Idean Salehyan. 2012. Elections and Social Conflict in Africa, 1990-2009. Paper presented at the 2012 Annual Convention of the International Studies Association. San Diego, Calif.

Linz, Juan, and A. Stepan. 1996. Problems of Democratic Transition and Consolidation: Southern Europe, South America, and Post-Communist Europe. Baltimore, Md.: Johns Hopkins University Press.

Lynch, Gabrielle, and Gordon Crawford. 2012. Democratization in Africa 1990-2010: An Assessment. Democratization 18 (2):275-310.

Makinda, Samuel. 1996. Democracy and Multi-Party Politics in Africa. Journal of Modern African Studies 34 (4):555-73.

Marshall, Monty, Ted Robert Gurr, and Keith Jaggers. 2012. Polity IV Project. Political Regime Characteristics and Transitions, 1800-2012. Dataset User's Manual. Available from http://www. systemicpeace.org/polity/polity4.htm, accessed January 2013.

Mozaffar, Shaheen. 1998. Electoral System and Conflict Management in Africa: A Twenty-Eight-State Comparison. Pp. 81-98 in Elections and Conflict Management in Africa, edited by Timothy Sisk and Andrew Reynolds. Washington, D.C.: United States Institute of Peace.

Mozaffar, Shaheen, and James Scarritt. 2005. The Puzzle of African Party Systems. Party Politics 11 (4): 399-421.

Mozaffar, Shaheen, James Scarritt, and Glen Galaich. 2003. Electoral Institutions, Ethnopolitical Cleavages, and Party Systems in Africa's Emerging Democracies. American Political Science Review 97 (3):379-90.

Mueller, Susanne D. 2008. The Political Economy of Kenya's Crisis. Journal of Eastern African Studies 2 (2): 185-210.

Norris, Pippa. 1995. The Politics of Electoral Reform. International Political Science Review 16 (1):3-8.

Persson, Torsten, and Guido Tabellini. 2003. The Economic Effects of Constitutions. Massachusetts: MIT Press.

—. 2004. Constitutions and Economic Policy. Journal of Economic Perspectives 18 (1):75-98.

Persson, Torsten, Guido Tabellini, and Francesco Trebbi. 2003. Electoral Rules and Corruption. Journal of the European Economic Association 1 (4):958-89.

Posner, Daniel N. 2004. Measuring Ethnic Fractionalization in Africa. American Journal of Political Science 48 (4):849-63.

Posner, Daniel. 2007. Regime Change and Ethnic Cleavages in Africa. Comparative Political Studies 40 (11):1302-27.

Posner, Daniel, and Daniel Young. 2007. The Institutionalization of Political Power in Africa. Journal of Democracy 18 (3):126-40.

Przeworski, Adam. 1991. Democracy and the Market: Political and Economic Reforms in Eastern Europe and Latin America. Cambridge: Cambridge University Press.

Rakner, Lise, and Nicolas van de Walle. 2009. Opposition Weakness in Africa. Journal of Democracy 20 (3):108-21.

Regan, Patrick, Richard Frank, and David Clark. 2009. New Dataset on Political Institutions and Elections. Conflict Management and Peace Science 26 (3):286-304.

Reilly, Benjamin, and Andrew Reynolds. 2000. Electoral Systems and Conflict in Divided Societies. Pp. 420-83 in International Conflict Resolution after the Cold War, edited by Paul Stern and Daniel Druckman. Washington, D.C.: National Academy Press. 
Reynal Querol, Marta. 2002. Ethnicity, Political Systems and Civil War. Journal of Conflict Resolution 46 (1):29-54.

Reynolds, Andrew. 1999. Electoral Systems and Democratization in Southern Africa. Oxford: Oxford University Press.

Saideman, Stephen, David Lanoue, Michael Campenni, and Samuel Stanton. 2002. Democratization, Political Institutions, and Ethnic Conflict: A Pooled Time-Series Analysis, 1985-1998. Comparative Political Studies 35 (1):103-29.

Salehyan, Idean, Cullen S. Hendrix, Jesse Hamner, Christina Case, Christopher Linebarger, Emily Stull, and Jennifer Williams. 2012. Social Conflict in Africa: A New Database. International Interactions 38 (4):503-11.

Scarritt, James, and Susan McMillan. 1995. Protest and Rebellion in Africa: Explaining Conflicts Between Minorities and the State in the 1980s. Comparative Political Studies 28 (3):323-49.

Schedler, Andreas. 2002. The Menu of Manipulation. Journal of Democracy 13:36-50.

- 2006. Electoral Authoritarianism: The Dynamics of Unfree Competition. Boulder and London: Lynne Rienner Publishers.

Schneider, Gerald and Nina Wiesehomeier. 2008. Rules That Matter: Political Institutions and the Diversity - Conflict Nexus. Journal of Peace Research 45 (2):183-203.

Selway, Joel, and Kharis Templeman. 2012. The Myth of Consociationalism? Conflict Reduction in Divided Societies. Comparative Political Studies 45 (2):1542-71.

Sisk, Timothy, 1996. Power Sharing and International Mediation in Ethnic Conflicts. Washington, D.C.: United States Institute of Peace.

Sisk, Timothy and Andrew Reynolds, eds. 1998. Elections and Conflict Management in Africa. Washington, D.C: United States Institute of Peace.

Southall, Roger. 2009. Alternatives for Electoral Reform in Kenya: Lessons from Southern Africa. Journal of Contemporary African Studies 27 (3):445-61.

Snyder, Jack. 2000. From Voting to Violence: Democratization and Nationalist Conflict. New York: Norton.

Straus, Scott, and Charlie Taylor. 2012. Democratization and Electoral Violence in Sub-Saharan Africa. Pp. 15-38 in Voting in Fear. Electoral Violence in Sub-Saharan Africa, edited by Dorina Bekoe. Washington, D.C.: United States Institute of Peace.

Stewart, Frances. 2008. Horizontal Inequalities and Conflict: Understanding Group Violence in Multiethnic Societies. Basingstoke, Hants.: Palgrave Macmillan.

Teorell, Jan, Marcus Samanni, Sören Holmberg, and Bo Rothstein. 2011. The Quality of Government Dataset, Version 6 April 2011. Available from http://www.qog.pol.gu.se, accessed 10 January 2013.

Tomz, Michael, Jason Wittenberg, and Gary King. 2003. Clarify: Software for Interpreting and Presenting Statistical Results. Available from http:// gking.harvard.edu/ Accessed on 1 March 2013.

United Nations. 2009. The National Accounts Main Aggregates Database. Available from http://unstats. un.org/unsd/snaama/Introduction.asp, accessed 10 January 2013.

Van Klinken, Gerry. 2002. Communal Violence and Democratization in Indonesia: Small Town Wars. London: Routledge.

Van de Walle, Nicolas. 2003. Presidentialism and Clientelism in Africa's Emerging Party Systems. Journal of Modern Africa Studies 41 (29):297-321.

Vanhanen, Tatu. 1997. Prospects of Democracy: A Study of 172 Countries. London: Routledge.

Wagner, Wolfgang, and Sofie Dreef. 2014. Ethnic Composition and Electoral System Design: Demographic Context Conditions for Post-Conflict Elections. Ethnopolitics 13 (3):288-307.

Wantchekon, Leonard. 2003. Clientelism and Voting Behavior: Evidence from a Field Experiment in Benin. World Politics 55 (3):399-422.

Weaver, Kent. 2002. Electoral Rules and Governability. Journal of Democracy 13 (2):111-25.

Wilkinson, Steven. 2004. Votes and Violence: Electoral Competition and Ethnic Riots in India. Cambridge: Cambridge University Press.

Wimmer, Andreas. 1997. Who Owns the State? Understanding Ethnic Conflict in Post-Colonial Societies. Nations and Nationalism 3 (4):631-65. 